\title{
Providing Visual Aids (Posters) for English Lesson Grade One in $A B C$ Elementary School
}

\author{
Johanna Limarsono \\ English Department, Faculty of Languages and Literature, Petra Christian University, Siwalankerto 121-131, \\ Surabaya 60236, INDONESIA \\ Email: annasue132@gmail.com
}

\begin{abstract}
This final project is based on the writer's internship in $A B C$ Elementary School from March 12th to June 8th, 2018. The writer thought that it was a good solution to make and provide posters as the final project because of the problem she found during her internship in $A B C$ Elementary School, that is, students' lack of English vocabulary. The students seemed they did not want to participate in the English learning because the English book used in class was quite difficult for grade one students. The writer created posters to provide the students learning tools so that the students can follow and participate the teaching-learning process actively. By having interesting posters with their uniqueness (3D poster, removable poster, and etcetera), the students are expected to feel more interested in knowing and learning English vocabulary. These posters can help to support the teaching-learning process.
\end{abstract}

Keywords: Posters, 3D Poster, English Vocabulary, Project

\section{INTRODUCTION}

The writer did her internship at $A B C$ Elementary School for 104.6 hours to fulfill the requirement of her study at the English Department. She started the internship from March 2018 to June 2018. This school is for elementary students from grade one until grade six, but the writer did her internship in the first grade class. The accreditation of this school is an A. The school personnel consist of the principal of the school, the vice principal for the curriculum, the vice principal for the student affairs, teachers, a librarian, a doctor and a nurse, administrative staff, securities, and janitors.

During her internship, she found three problems in the teaching tasks. The first problem was the students' lack of English vocabulary. Lacking English vocabulary would be a serious problem that the students face because it affects the teaching and learning process. For example, in $A B C$ Elementary School the students could not follow the teaching and learning process because they did not understand the meaning of the words that the teacher said. The lack of vocabulary could be a serious problem in learning a foreign language if the students are not interested in enriching their vocabulary. Vocabulary is the basic part to learn a foreign language (Susanto, 2017). The problem of students' lack of English vocabulary could lower the students' interest in following the teachinglearning process. Then, the second problem was the material used to teach English lesson in grade one was quite hard. The writer thought that the English book that the students used in class was not compatible with students' level, especially the exercises of the English book. The students needed more time to understand the English book because it was quite difficult for them to comprehend the words. The last problem was the library lacked English books. The lack of English books in the library could decrease the students' interest in learning English because they could not find many sources to be read. From the three problems, the writer wants to focus on the first problem, that is, students' lack of English vocabulary.

The writer would like to provide five vocabulary posters as the solution of the problem. Then, the teacher can display one of the posters on the wall magazine so that the students can take a look at the poster every day. The poster is changed once a month so that the students do not learn only the same vocabulary in one semester. They can enrich their vocabulary when they take a look at the posters. The posters the writer made is not similar to the ones sold. The difference between the posters that the writer made and those sold in the markets is that the writer's posters include some games and interesting designs such as 3D design, and etcetera. 


\section{METHODS}

Before doing this project, the writer did an internship at $A B C$ Elementary School. The writer collected her internship report on July $25^{\text {th }}, 2018$ to the principal of the school and the English teacher in $A B C$ Elementary School. The writer discussed the problems she found during her internship: the students' lack of English vocabulary and their need to know and remember more English words. She also suggested the solution that she wanted to offer to the school. The solution was by providing poster as the visual aids for students in $A B C$ Elementary School. The poster could be displayed on the wall magazine so that the students could take a look and learn English vocabulary with the pictures on the poster every day. The writer would provide five posters so that the teacher could change the poster once a month and the students could learn and enrich many new English words in one semester.

The headmaster and the English teacher of grade one agreed with the writer's idea to make and provide posters for their students. They also agreed to display the posters as a wall magazine of grade one classroom. The wall magazine is made of Styrofoam, which means the poster should be light and easy to be attached with tacks. Then, the writer gave some suggestions to use art paper for the posters material. The principal of the school and the English teacher agreed with the writer's idea.

After the discussion, the writer got an approval from the English Department to conduct this final project. Then, the writer started to find an illustrator to draw or create pictures for the five posters she would like to make. The writer found an illustrator who has graduated from Design Communication Visual Department. The writer told her ideas about the posters that she would like to make to the illustrator. Then, the illustrator agreed to help the writer in making these five posters.

The words that the writer used for the posters were taken from the English book the teacher used during the writer's internship in $A B C$ Elementary School. The English book consisted of nine chapters. The writer chose the words students needed to know and learn through five chapters of the English book the teacher used during the writer's internship because these words were the basic English words.

The writer chose the things found in the classroom for thematic organization of vocabulary. There were ten words of the things found in the classroom: bag, book, chair, desk, pencil, pencil case, marker, rubber, ruler, and whiteboard. The writer chose these ten words because they were related to the students' real situation that they could meet in the classroom. Then, the writer chose also parts of the body for organization of vocabulary through relations of whole-parts. There were fifteen words for this poster: hair, head, eye, nose, mouth, ear, neck, shoulder, arm, hand, finger, leg, knee, foot, and toes. The writer chose these fifteen words because it is important for them to recognize their own parts of the body and to know the English names for their parts of the body. The next organization of vocabulary is antonym. It consisted of three prepositional words which had meanings somewhat related through antonymy: on, in, and under. The writer chose these three words because it was important for them to know how to say or give direction about the location of something. The last organization of vocabulary that the writer chose is 'ad-hoc' categories. "Ad-hoc categories are constructed to achieve specific communicative goals and depend on context for their interpretation (e.g. activities one can do at home), are usually less established in memory and less easily mastered by speakers than common categories" (Leadhoc Project, n.d.). The organization of vocabulary in 'adhoc' categories the writer chose were about clothes and days of the week. There were ten words of clothes' category: cap, t-shirt, jacket, sweater, jeans, trousers, skirt, shorts, socks, and shoes. These ten words of clothes were chosen so that the students could know and write the name of clothes that they might use in their daily life. The last poster was the category of days of the week which consisted of seven days: Monday, Tuesday, Wednesday, Thursday, Friday, Saturday, and Sunday. The writer chose these seven words so that it would be easy for the students to remember and write the arrangement of days of the week.

The writer discussed the posters material with the principal of the school and the English teacher in $A B C$ Elementary School. They agreed to use art paper as the material of the posters because it was light. The posters would be displayed on the wall magazine in the classroom so that all the students could read them. The writer also discussed the pictures and the design for the posters and they agreed with the writer's idea. 
The writer consulted the posters that she made with an illustrator. She gave her ideas to the illustrator so that the illustrator could draw the pictures that would be printed in the art paper. Then, the writer added some 3D designs in the posters to make it more interesting. What was meant by posters with 3D design here was a poster contained pictures in a form appear to be physically present with a designated structure. The size of the art paper is A3 which is $297 \mathrm{x} 420 \mathrm{~mm}$ (Millimeter) or 11,7 x 16,5" (inches). The writer has chosen 230 gsm and 150 gsm (Grams per Square Meter) as the paper weight because it is the medium weight of art paper and it will be easy to be attached on the wall magazine. The posters would be affixed with tacks. The example of 3D design picture is below:

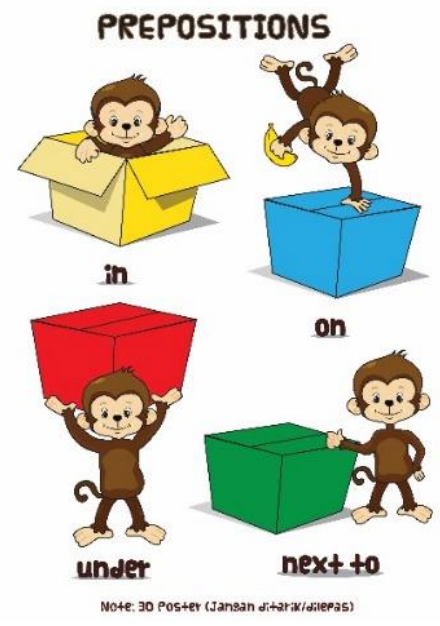

The writer used bright colors for the posters, such as blue, green, red, yellow, orange, and etcetera as the dominant colors to catch the young learners' attention. The color for the words were black so that the words would be clear to be seen by the learners. Then, the pictures for the posters were animation pictures so that the young learners would be more interested in reading them. The writer made five posters with a different number of words on each posters. The total of the words of the five posters were forty-five words.

After making the posters, the writer brought her product (vocabulary posters) to the school. She showed the posters to the principal and the English teacher of $A B C$ Elementary School. The principal of the school gave her feedback about the posters. She told the writer that she should add one word of prepositions, namely: 'next to'. Therefore, the words of 'Prepositions' poster became four words. Thus, the total of the words of the five vocabulary posters were forty-six words.

\section{ANALYSIS AND SOLUTION}

In the making of these five vocabulary posters, there are some specifications of the product that the writer would like to discuss in detail. The content of this product is vocabulary that includes pictures and English vocabulary. The first poster, namely: 'Things in the classroom' is under thematic organization of vocabulary because this poster describes the classroom's situation. It is the things that happen together like the objects and the place (Cameron, 2001). Then, the second poster, namely: 'Parts of the body' is under organization of vocabulary through relations of whole parts. The writer chose this organization for 'Parts of the body' poster because the example from the theory of organization of vocabulary through relations of whole parts is the same as this poster's title. After that, the third poster, namely: 'Prepositions' is under antonym vocabulary. This poster is under antonym vocabulary because this poster includes prepositions words that is the opposite. For example, 'in' and 'under' are antonyms. 'In' is located above something and 'under' is located below something. The fourth and the last posters are 'Clothes' and 'Days of the week'. These two posters are under 'ad-hoc' categories because 'Clothes' and 'Days of the week' are the name given to collections of things put together on the spur of the moment. This 'ad-hoc' category also refers to the unit that has a set of vocabulary items introduced through pictures.

The language used for this product is English. The hardware of this product is art paper, glue, Velcro, and foam. The software of this product is Adobe Illustrator application. The font for all of 
the texts on the posters that the writer uses is Funnier because the font seems compatible with the young learners. This Funnier font is also clear and suitable for children's poster. The example of Funnier font is below:

\section{Funnier}

The font size on each poster is different because the pictures on each poster are also different. On 'Parts of the Body' poster, the title's font size is 44. The English words on the poster are 26 and 20 because the writer created poster that some pictures can be opened like a 'window' on this poster. Therefore, the font sizes are different from the words that can be seen directly. Then, on 'Things in the classroom', the title's font size is 36 and the English words are 20. The font sizes are different so that the students can know the differentiation between the title and the English words on the poster. The orientation of this poster is in landscape so that it can create the classroom situation. The font is smaller than 'Things in the classroom' poster because this poster needs to include things with more distance. Then, the title's font size of 'Clothes' is 44 and the English words are in different sizes: 18, 15 , and 9. The font sizes of the poster are different because the picture sizes are also different like shoes and socks are smaller than t-shirt or jacket on the poster. After that, on 'Prepositions' poster, the title's font size is 44 and the English words are 36 . The writer differentiated the fonts so that the young learners can recognize the title and the English words. There is an information below the 'Prepositions' pictures: "Note: 3D Poster (Jangan ditarik/dilepas)". The writer used Bahasa Indonesia to make clear to the students that the pictures on the poster could not be detached. The font size is 18. Then, on 'Days of the Week', the title's font size is 46 and the English words are 42. The writer used different fonts so that the young learners can recognize the title and English words.

These five posters have different systems. The posters entitled 'Clothes' and 'Days of the Week' are removable. The pictures of these posters can be taken out and attached again to match the position with the right vocabulary. The writer uses Velcro to make these posters be able to be taken out and attached. The poster of 'Parts of the Body' is different from others. Some words in this poster can be seen only, but some others can be opened like a 'window'. The posters entitled 'Prepositions' and 'Things in the Classroom' are in 3D pictures. Some pictures of these posters are also removable.

This product has its strengths and limitations. The strengths of this product is the uniqueness of the product that makes this product interesting. This product helps students to learn in a fun way since some pictures in the posters are removable, while others are 3D pictures, and the others can be opened like a 'window'. The use of Velcro here also makes easy for the learners to attach the pictures with the right vocabulary because it has some indirect instructions on the posters. The students can directly understand how to use or play with the posters by looking at them. This product (the five vocabulary posters) is made of art paper so that it can be cleaned with dry cloth or tissue when it is dusty. The limitations of this product is the possibility of the pictures to be detached because of the glue that the writer uses. Therefore, the learners should be careful when they remove the pictures using Velcro for the poster; otherwise, the posters will be damaged. Another limitation of this product is the art paper itself that the writer uses. It is possible if the paper can be torn up because it is made of art paper. For example, if the poster is spilled by water, it will be damaged or torn out. That is why the users of this product should use the product carefully.

The writer made this product because she saw that the grade one students in $A B C$ Elementary School need to enrich their English vocabulary. The teacher needs to introduce the English vocabulary to young learners so that they can understand and follow the teaching-learning process in class. The teacher also needs to create a situation that makes the students feel that it is not their responsibility to learn, but it is the students themselves who want to know or feel curios about what they learn about. These five posters can help the students to remember and learn English vocabulary in a fun way.

The writer provided interesting posters for young learners as the project product because of several reasons. First of all, the writer chose posters because posters support the teaching-learning process more rather than labels, messages, or reading aloud like she mentioned in chapter two. When students find a new thing that is interesting in their classroom, they will get curios and want to find out. The poster can attract the students' attention to see and learn about it. Using labels or messages, or reading aloud (using 'big' books) can only be used when the teacher is teaching the English 
subject. On the contrary, by using poster, the students can learn the English words anytime because it is attached on the wall magazine in the classroom. The students are in grade one so that they need something eye-catching that can make them feel curios and want to learn. Then, these five posters include clear pictures and English words that show things they need to know and remember about. The pictures in the posters show or represent the real objects that the students can find in real life. After that, these five posters have bright colored pictures that attract the learners' attention to learn English vocabulary such as red, blue, green, yellow and other bright colors.

\section{CONCLUSION}

The main problem of students' lack of English vocabulary gave the writer the idea of how to get the students' interest or attention to learn and remember English words. The writer gave her best solution to solve the main problem in $A B C$ Elementary School by making and providing interesting posters. These five interesting vocabulary posters as the solution are designed to get the learners' attention. The writer believes that these five posters can boost the learners' interest to learn English words because of the designs, colors, pictures, and the system of the posters themselves. The students can be more excited and curious to learn the English vocabulary. The design of these five posters that the writer made is different from the ones sold at the market because some posters are designed $3 \mathrm{D}$, some are removable, and some are designed like a window that can be opened. Not only the designs that are interesting and unique, but also the colors of the posters are bright so that the young learners can have fun to learn English vocabulary. The pictures on the posters are also clear, and they represent a real situation or thing in real life which means the students can easily understand what the meaning of the words on the posters is.

There are some recommendations that the writer wanted to give for further project. Firstly, the writer suggested to pay attention to the place for the poster like the space and where it will be attached or displayed. Thus, it can be considered what materials of the poster can be used for creating and making the poster. Then, the writer suggested to consider the font and picture's size to be able to be seen clearly. The last, the writer suggested to consider the weight of the poster so that it will not fall down when it is attached or displayed.

Based on the writer's analysis of making and providing posters for students in $A B C$ Elementary School, it revealed that these five vocabulary posters are very good in enriching the students' English vocabulary. However, the poster should be changed once a month so that the students can learn many English words in one semester. Therefore, the writer provides not only one poster, but five posters that contain different pictures and English words on them. Hopefully, these five vocabulary posters can be useful and advantageous for both the teacher and students in the teaching-learning process.

\section{REFERENCES}

Cameron, L. (2001). Teaching Languages to Young Learners. Cambridge: Cambridge University Press.

Leadhoc Project. (n.d.) The linguistic expression of ad hoc categories. Retrieved October 16, 2018, from http://www.leadhoc.org/

Susanto, A. (2017, October). The teaching of vocabulary: A perspective. Retrieved July, 8, 2018, from https://www.researchgate.net/publication/320571421_THE_TEACHING_OF_VOCABULA RY_A_PERSPECTIVE 